\title{
KARAKTERISTIK CAMPURAN PANAS ASPHALT CONCRETE WEARING COURSE (AC-WC) MENGGUNAKAN SEMARBUT ASPAL TIPE III SEBAGAI BINDER (MODIFIKASI ASPAL PENETRASI 60/70 DENGAN EKSTRAKSI ASBUTON EMULSI BAHAN PEREMAJA OLI BEKAS)
}

\author{
Djoko Sarwono ${ }^{1)}$, Djumari ${ }^{2)}$, Muhammad Rifa'i ${ }^{3)}$ \\ 1) 2) 3) Roadmate Research Group, Teknik Sipil, Universitas Sebelas Maret \\ Roadmate Research Group, Laboratorium Jalan Raya, Fakultas Teknik, Universitas Sebelas Maret \\ E-mail : sarwono60@yahoo.co.id, djumari.sipil@gmail.com, muhrifai73@gmail.com
}

\begin{abstract}
Asphalt Semarbut Type III is an asphalt obtained from penetration asphalt 60/70 mixture with extraction emulsion asbuton of used oil rejuvenation materials. This asphalt is a modified asphalt developed to improve the characteristics of asbuton extracted. Modification of asphalt is done because asbuton extraction results when stand alone as a binder on the road pavement has not been able to give maximum results. The purpose of this research is to know the performance and characteristics of Marshall and Tensile Strength of AC-WC bot mix by using Asphalt Semarbut Type III. This research uses experimental method in Laboratory. There are two testing performed consisting Marshall Test and Tensile Strength. From the result of Marshall test obtained the value of optimum bitumen content. The value of the optimum bitumen content is used for the manufacture of specimens on Tensile Strength test by using Indirect Tensile Strength test method. The result of the test obtained the ITS corrected value, strain value, and modulus elasticity value. The result of data analysis obtained Marshall characteristic value and Tensile Strength on AC-WC hot mix with optimum asphalt content of 5,93\%. Marshall characteristic values with compactor such as stability, flow, and density have fullfil the specifications, whereas for Marshall Quotient $(459,3 \mathrm{~kg} / \mathrm{mm})$ and VIM (5,96\%) values have not fullfil the specification. Tensile Strength test results obtained elasticity modulus value of 18,59 ksi, the results show that the value of modulus elasticity is still low and has not fulfilled the requirement of 500-2000 ksi. Marshall characteristic values with vibrator such as flow, and density have fullfil the specifications, whereas for stability $(374,71 \mathrm{KPa})$, Marshall Quotient $(459,3 \mathrm{~kg} / \mathrm{mm})$ and VIM $(5,96 \%)$ values have not fullfil the specification. Tensile Strength test results obtained elasticity modulus value of 4,49 Ksi, the results is lower when compared with sample of compactor
\end{abstract}

Keyword: Asphalt Semarbut Type III, Marshall, Tensile Strength

\begin{abstract}
Abstrak
Semarbut Aspal Tipe III merupakan aspal yang diperoleh dari campuran aspal penetrasi 60/70 dengan ekstrak asbuton emulsi bahan peremaja oli bekas. Aspal ini merupakan aspal modifikasi yang dikembangkan untuk memperbaiki karakteristik asbuton hasil ekstraksi. Modifikasi aspal dilakukan karena asbuton hasil ekstraksi apabila berdiri sendiri sebagai bahan pengikat pada perkerasan jalan raya belum bisa memberikan hasil yang maksimal. Tujuan dari penelitian ini untuk mengetahui karakteristik Marshall dan Kuat Tarik pada campuran panas AC-WC menggunakan Semarbut Aspal Tipe III. Penelitian ini menggunakan metode eksperimental di Laboratorium. Ada dua pengujian yang dilakukan, yaitu pengujian Marshall dan Kuat Tarik. Dari hasil pengujian Marshall diperoleh nilai kadar aspal optimum. Nilai kadar aspal optimum kemudian digunakan untuk pembuatan benda uji pada pengujian Kuat Tarik dengan menggunakan metode Kuat Tarik Tidak Langsung. Hasil dari pengujian tersebut didapatkan nilai ITS terkoreksi, nilai regangan, dan nilai modulus elastisitas. Hasil analisis data diperoleh nilai karakterisktik Marshall dan Kuat Tarik pada campuran panas AC-WC dengan kadar aspal optimum 5,93\%. Nilai karakteristik Marshall dengan alat compactor seperti stabilitas, flow, dan kepadatan telah memenuhi spesifikasi, sedangkan untuk nilai Marshall Quotient (459,3 $\mathrm{kg} / \mathrm{mm})$ dan VIM $(5,96 \%)$ belum memenuhi spesifikasi. Hasil pengujian Kuat Tarik diperoleh nilai modulus elastisitas sebesar 18,59 Ksi, hasil tersebut menunjukkan, bahwa nilai modulus elastisitas masih rendah dan belum memenuhi persyaratan sebesar 500-2000 ksi. Nilai karakteristik Marshall dengan alat vibrator seperti flow, dan kepadatan telah memenuhi spesifikasi, sedangkan untuk nilai stabilitas (374,71 KPa), Marshall Quotient (459,3 kg/mm) dan VIM (5,96\%) belum memenuhi spesifikasi. Pengujian Kuat Tarik diperoleh nilai modulus elastisitas sebesar 4,49 Ksi, hasil tersebut lebih rendah jika dibandingkan dengan benda uji alat compactor.
\end{abstract}

Kata Kunci: Semarbut Aspal Tipe III, Marshall, Kuat Tarik

\section{PENDAHULUAN}

Penelitian ini menggunakan data sekunder dari penelitian sebelumnya yang berjudul "Karakteristik Ekstraksi Asbuton dengan Metode Asbuton Emulsi Menggunakan Bahan Peremaja Oli Bekas dan Karakteristik Penambahan Ekstraksi Asbuton Emulsi Pada Aspal Penetrasi 60/70 (Semarbut Aspal Tipe III)". Data sekunder yang digunakan berupa proporsi campuran dan properti Semarbut Aspal Tipe III. Semarbut Aspal Tipe III adalah modifikasi ekstraksi asbuton emulsi dengan aspal minyak penetrasi 60/70. Perbedaan antara Semarbut Aspal Tipe I, II, dan III adalah terletak pada bahan peremaja yang digunakan pada saat ekstraksi asbuton emulsi. Penelitian Semarbut Aspal Tipe I dan II masing-masing menggunakan bahan peremaja kerosin dan premium, sedangkan pada penelitian Semarbut Aspal Tipe III menggunakan bahan peremaja berupa oli bekas. Berdasarkan penelitain sebelumnya didapatkan proporsi campuran Semarbut Aspal Tipe III yang terdiri dari 30\% ekstraksi asbuton emulsi dan 70\% 
aspal penetrasi 60/70 untuk selanjutnya digunakan untuk membuat campuran aspal. Jenis campuran yang digunakan pada penelitian ini adalah campuran panas AC-WC. Campuran panas AC-WC dipilih karena berdasarkan penelitian sebelumnya hasil yang diperoleh menunjukkan nilai stabilitas dan VIM yang rendah. Ada dua tahapan pengujian yang dilakukan pada penelitian ini terdiri dari pengujian Marshall dan Kuat Tarik dengan menggunakan metode Kuat Tarik Tidak Langsung. Tujuan dari pengujian tersebut untuk mengetahui nilai karakteristik campuran beraspal. Penelitian ini diharapkan mampu meningkatkan kualitas Semarbut Aspal dan nilai karakteristik campuran panas AC-WC sehingga menghasilkan campuran yang cenderung tidak kaku.

\section{TINJAUAN PUSTAKA}

Penelitian oleh Petrich Meysha Buana R (2013) yang berjudul "Tinjauan Karakteristik Marshall dan Kuat Tarik Tidak Langsung Campuran Panas Aspal beton Menggunakan Semarbut Aspal Tipe I Sebagai Binder", penelitian ini bertujuan untuk meninjau nilai karakteristik Marshall dan Indirect Tensile Strength (ITS) campuran panas Aspal Beton. Hasil penelitian ini diperoleh nilai stabilitas sebesar $627,175 \mathrm{~kg}$, nilai densitas sebesar 2,123 gram/cc, nilai porositas sebesar 9,958\%, nilai flow sebesar 2,02 mm, dan nilai Marshall Quotient sebesar 310,483 kg/mm. Sedangkan untuk nilai karakteristik Indirect Tensile Strength diperoleh ITS terkoreksi sebesar 474,407 Kpa, nilai regangan sebesar 0,008002 dan nilai modulus elastis sebesar 59614,51 Kpa. Nilai modulus elastisitas dari hasil penelitian masih dibawah persyaratan aspal beton sehingga sifat campuran cenderung kaku.

Penelitian oleh Mentari C. P Mantong (2014) yang berjudul "Pengujian Kinerja Campuran (AC-WC) Substitusi Buton Granular Aspal Sebagai Bahan Pengikat dengan Metode Marshall". Penelitian ini menunjukkan hasil pengujian Marshall dapat memenuhi spesifikasi campuran AC-WC (Asphalt Concrete Wearing Course). Nilai Kadar Optimum yang diperoleh dari hasil analisis karakteristik Marshall yaitu sebesar 6,9\%.

Penelitian oleh Lazuardy Firmansyah Putra (2016) yang berjudul "Karakteristik Campuran Panas Asphalt Concrete Wearing Course dengan Bahan Pengikat Semarbut Tipe II", penelitian ini bertujuan untuk meninjau nilai karakteristik Marshall dan Indirect Tensile Strength (ITS) campuran panas Aspal Beton. Hasil penelitian ini diperoleh nilai stabilitas campuran sebesar 1674,93 kg, nilai kepadatan sebesar 2,386 gram/cc, nilai porositas (VIM) sebesar 4,01\%, nilai flow sebesar 4,6 mm, dan nilai Marshall Quotient sebesar 359,074 kg/mm. Sedangkan untuk nilai karakteristik Indirect Tensile Strength diperoleh ITS terkoreksi sebesar 358,73 KPa, nilai regangan sebesar 0,0038 dan nilai modulus elastisitas sebesar 13,99 Ksi. Nilai modulus elastisitas yang rendah menyebabkan sifat campuran cenderung kaku.

\section{DASAR TEORI}

\section{AC-WC (Asphalt Concrete Wearing Course)}

AC-WC merupakan lapisan yang behubungan langsung dengan beban roda kendaraan dan dirancang untuk tahan terhadap perubahan suhu, gaya geser, beban vertical, dan lapis kedap air. Tebal minimum untuk lapisan AC-WC adalah $4 \mathrm{~cm}$. Dalam penggunaannya AC-WC merupakan lapis permukaan yang letaknya paling atas pada permukaan perkerasan jalan raya dan mempunyai tekstur yang paling halus. Gradasi yang dipakai pada campuran AC-WC yaitu gradasi menerus dengan sedikit rongga dalam struktur agregatnya.

\section{Material Penyusun Campuran Asphalt Concrete Wearing Course}

Material penyusun campuran aspal adalah agregat dan aspal. Berikut material penyusun aspal beton AC-WC:

\section{Agregat}

Agregat adalah salah satu komponen struktur perkerasan jalan beraspal yang mempunyai persentase yang paling besar. Oleh karena itu kualitas perkerasan jalan beraspal sangat dipengaruhi oleh kualitas dari agregat itu sendiri. Kualitas agregat sebagai komponen struktur perkerasan jalan beraspal ditentukan oleh gradasi, kebersihan, kekerasan, ketahanan agregat, bentuk butir, tekstur permukaan, porositas, kemampuan untuk menyerap air, berat jenis, dan daya kelekatan terhadap aspal. Agregat dapat berupa butir-butir batu pecah, kerikil, pasir atau mineral lain, baik yang berasal dari alam ataupun yang berbentuk mineral padat dengan berbagai ukuran. Berdasarkan ukurannya agregat dibagi emnjadi 3 yaitu agregat kasar, agregat halus, dan filler.

\section{Aspal Modifikasi}

Aspal modifikasi adalah aspal yang dibuat dengan cara mencampur aspal keras dengan suatu bahan tambah. Salah satu produk dari aspal modifikasi yaitu Semarbut Aspal Tipe III. Semarbut Tipe III adalah modifikasi aspal penetrasi 60/70 dengan ekstrak asbuton emulsi bahan peremaja oli bekas. Proses modifikasi aspal yang dimaksud yaitu dengan cara mencampurkan antara ekstrak asbuton emulsi sebanyak 30\% dan aspal penetrasi 60/70 sebanyak 
70\%. Pencampuran dilakukan dengan menggunakan metode panas-panas, dicampur sampai menjadi homogen dengan suhu di atas $100^{\circ} \mathrm{C}$. Persyaratan yang digunakan berdasarakan persyaratan aspal dimodifikasi dengan asbuton seperti yang ditunjukkan pada Tabel 1.

Tabel 1. Persyaratan Aspal Dimodifikasi dengan Asbuton

\begin{tabular}{cllc}
\hline No & \multicolumn{1}{c}{ Jenis Pengujian } & \multicolumn{1}{c}{ Metode } & Persyaratan \\
\hline 1. & Penetrasi $25^{\circ} \mathrm{C}, 100 \mathrm{gr}, 5$ detik, $0,1 \mathrm{~mm}$ & SNI 06-2456-1991 & $40-60$ \\
2. & Titik Lembek $\left({ }^{\circ} \mathrm{C}\right)$ & SNI 06-2434-1991 & Min. 55 \\
3. & Titik Nyala $\left({ }^{\circ} \mathrm{C}\right)$ & SNI 06-2433-1991 & Min. 225 \\
4. & Daktilitas $25^{\circ} \mathrm{C}, 5 \mathrm{~cm} /$ menit $(\mathrm{cm})$ & SNI 06-2432-1991 & Min. 50 \\
5. & Berat Jenis $(\mathrm{gr} / \mathrm{cc})$ & SNI 06-2441-1991 & Min. 1,0 \\
\hline \multicolumn{2}{l}{ Sumber: Pemanfaatan Asbuton. Pedoman No: $001-01$ / BM / 2006, Direktorat Jendral Bina Marga }
\end{tabular}

\section{Karakteristik Campuran Panas Asphalt Concrete Wearing Course}

Berdasarkan SNI 03-1719-1989 tentang Tata Cara Pelaksanaan Lapisan Aspal Beton (Laston) Untuk Jalan Raya, campuran beraspal yang digunakan harus memenuhi karakteristik tertentu agar dapat menahan beban lalu lintas seperti yang ditunjukkan pada Tabel 2.

Tabel 2. Spesifikasi Sifat Campuran Aspal Beton

\begin{tabular}{|c|c|c|c|c|c|c|}
\hline \multirow{3}{*}{ Sifat Campuran } & \multicolumn{2}{|c|}{ Lalu Lintas Berat } & \multicolumn{2}{|c|}{ Lalu Lintas Sedang } & \multicolumn{2}{|c|}{ Lalu Lintas Ringan } \\
\hline & $(2 \times 75)$ & umbukan & $(2 \times 50)$ & imbukan & $(2 \times 35)$ & umbukan \\
\hline & Minimal & Maksimal & Minimal & Maksimal & Minimal & Maksimal \\
\hline Stablitas $(\mathrm{kg})$ & 550 & - & 450 & - & 350 & - \\
\hline Flow (mm) & 2,0 & 4,0 & 2,0 & 4,5 & 2,0 & 5,0 \\
\hline MQ (kg/mm) & 200 & 350 & 200 & 350 & 200 & 350 \\
\hline Kepadatan (gr/cc) & 2 & 3 & 2 & 3 & 2 & 3 \\
\hline VIM $(\%)$ & 3 & 5 & 3 & 5 & 3 & 5 \\
\hline VFB (\%) & 75 & 82 & 75 & 85 & 75 & 85 \\
\hline
\end{tabular}

\section{METODOLOGI PENELITIAN}

Penelitian ini terdiri dari dua pengujian diantaranya, uji Marshall dan Kuat Tarik menggunakan metode Kuat Tarik Tidak Langsung pada campuran panas asphalt concrete wearing course (AC-WC) dengan bahan pengikat Semarbut Aspal Tipe III. Pengujian menggunakan metode eksperimental di laboratorium. Pada tahap awal penelitian dilakukan pemeriksaan bahan penelitian yang terdiri dari pemeriksaan agregat dan property Semarbut Aspal Tipe III. Setelah dilakukan pemeriksaan bahan penelitian selanjutnya dilakukakn pengujian Marshall. Benda uji yang digunakan pada pengujian Marshall terdiri dari 3 benda uji untuk setiap kadar aspal. Sebelum pengujian Marshall, dilakukan uji volumetrik terhadap benda uji untuk mendapatkan data nilai kepadatan, VIM, VMA, VFB, dan berat jenis campuran. Dari hasil pengujian Marshall akan didapatkan nilai kadar aspal optimum yang nantinya digunakan untuk pembuatan benda uji untuk pengujian kuat tarik. Hasil dari pengujian tersebut didapatkan nilai karakteristik kuat tarik campuran aspal seperti ITS terkoreksi, regangan, dan modulus elastisitas. Selain itu pada penelitian ini dilakukan pembuatan benda uji plat dengan pemadatan menggunakan alat vibrator. Hasil yang diperoleh kemudian dibandingkan dengan benda uji alat pemadat compactor. Analisis data yang digunakan adalah analisis regresi dan analisi korelasi. Analisis regresi digunakan untuk mengetahui pola relasi atau hubungan antara variabel terikat dan variabel bebas. Variabel terikat adalah nilai karakteristik hasil pengujian Marshall, sedangkan variabel bebas adalah kadar aspal optimum rencana (Semarbut Aspal Tipe III). Analisis korelasi digunakan untuk mencari hubungan dua variabel atau leih secara kuantitatif untuk menggambarkan derajat keeratan linearitas variabel terikat dengan variabel bebas, untuk mengukur seberapa tepat garis regresi menjelaskan variasi variabel terikat.

\section{HASIL DAN PEMBAHASAN}

\section{Data Pemeriksaan Agregat}

Pemeriksaan agregat yang dilakukan meliputi: uji keausan dengan mesin Los Angeles, uji berat jenis dan penyerapan agregat. Pada pengujian keausan course aggregate (CA) dengan menggunakan mesin Los Angles diperoleh nilai keausan sebesar 25,4\%, nilai keasusan tersebut memenuhi persyaratan SNI 03-2417-1991 dengan syarat nilai keausan maksimum 40\%. Hasil pengujian agregat dapat ditunjukkan pada Tabel 3. 
Tabel 3. Hasil Pengujian Agregat

\begin{tabular}{clcccc}
\hline No & \multicolumn{1}{c}{ Jenis Pengujian } & Hasil CA & Hasil MA & Hasil FA & Spesifikasi \\
\hline 1. & Penyerapan $(\%)$ & 1,079 & 1,382 & 2,271 & Maks. 3 \\
2. & Berat Jenis Bulk $(\%)$ & 2,632 & 2,647 & 2,521 & Min. 2,5 \\
3. & Berat Jenis SSD $(\%)$ & 2,661 & 2,684 & 2,578 & Min. 2,5 \\
4. & Berat Jenis Apparent $(\%)$ & 2,710 & 2,747 & 2,674 & - \\
\hline
\end{tabular}

Sumber: Laboratorium Jalan Raya UNS 2017

\section{Data Pemeriksaan Semarbut Aspal Tipe III}

Semarbut Aspal Tipe III merupakan pengembangan dari Semarbut Aspal Tipe II. Aspal ini merupakan aspal modifikasi antara aspal penetrasi 60/70 dengan ekstraksi asbuton emulsi bahan peremaja oli bekas. Berdasarkan penelitian sebelumnya diperoleh kadar optimum campuran antara ekstraksi asbuton emulsi $30 \%$ dan aspal penetrasi 60/70 70\%. Hasil pengujian Semarbut aspal Tipe III dapat ditunjukkan pada Tabel 4.

Tabel 4. Hasil Pengujian Semarbut Aspal Tipe III

\begin{tabular}{clc}
\hline No. & Jenis Pengujian & Hasil \\
\hline 1. & Penetrasi (x10-1 $\mathrm{mm})$ & 57 \\
2. & Daktilitas (cm) & 55,5 \\
3. & Titik Lembek (C) & 57 \\
4. & Titik Nyala (C) & 290 \\
5. & Titik Bakar (C) & 310 \\
6. & Berat Jenis (gr/cc) & 1,146 \\
\hline Sumber: & (Devi Prapita Nuari, 2017)
\end{tabular}

\section{Data Perencanaan Gradasi}

Perencanaan gradasi campuran untuk pembuatan benda uji disesuaikan dengan SNI 03-1737-1989 tentang Tata Cara Pelaksanaan Lapis aspal Beton (Laston) Untuk Jalan Raya. Gradasi campuran yang digunakan yaitu spesifikasi campuran No. VII dengan data gradasi menggunakan median dari spesifikasi tersebut, seperti yang ditunjukkan pada Tabel 5.

Tabel 5. Perencanaan Gradasi Campuran

\begin{tabular}{ccccc}
\hline $\begin{array}{c}\text { No. } \\
\text { Saringan }\end{array}$ & \multicolumn{3}{c}{$\begin{array}{c}\text { Spesifikasi Campuran } \\
\text { No. VII }\end{array}$} & Gradasi \\
\hline $3 / 4 "$ & \multicolumn{3}{c}{100} & 100,00 \\
$1 / 2 "$ & 80 & - & 100 & 90,00 \\
$\# 4$ & 54 & - & 72 & 63,00 \\
$\# 8$ & 42 & - & 58 & 50,00 \\
$\# 30$ & 26 & - & 38 & 32,00 \\
$\# 50$ & 18 & - & 28 & 23,00 \\
$\# 100$ & 12 & - & 20 & 16,00 \\
$\# 200$ & 6 & - & 12 & 9,00 \\
PAN & & & & 0,00 \\
\hline
\end{tabular}

Sumber: SNI 03-1737-1989

\section{Data Kadar Aspal Rencana (Pb)}

Berdasarkan Pedoman Teknik No.028 / T / BM / 1999, perhitungan kadar aspal optimum rencana (Pb) dapat dilakukan dengan menggunakan persamaan di bawah ini:

$\mathrm{Pb}=0,035(\% \mathrm{CA})+0,045(\% \mathrm{FA})+0,18(\% \mathrm{FF})+$ konstanta

$$
=0,035 \times(100-50)+0,045(50-9)+0,18 \times(9)+1
$$

$\mathrm{Pb}=6,215 \% \approx 6 \%$ (Kadar Semarbut Aspal Tipe III yang dipakai dalam penelitian ini adalah 5\% - 7\%)

Dimana: \%CA : \% berat agregat yang tertahan saringan no.8 terhadap berat total campuran

$\% \mathrm{FA} \quad \%$ berat agregat yang lolos saringan no. 8 dan tertahan saringan no. 200 terhadap berat total campuran

$\%$ Filler : \% berat agregat yang lolos saringan no.200 terhadap berat total campuran

K : konstanta (0,5-1 untuk laston; 2-3 untuk lataston; 1-2,5 untuk campuran lain). 


\section{Hasil Analisis Volumetrik Benda Uji Marshall}

Pembuatan benda uji untuk pengujian Marshall telah disesuaikan dengan SNI 3-1737-1989. Berikut data hasil analisis volumetrik benda uji untuk pengujian Marshall ditunjukkan pada Tabel 6.

Tabel 6. Hasil Pembuatan Benda Uji

\begin{tabular}{ccccccc}
\hline Kode Benda Uji & Kadar Aspal $(\%)$ & Koreksi Tebal $(\mathrm{cm})$ & Kepadatan & $V M A(\%)$ & $V I M(\%)$ & $V F B(\%)$ \\
\hline 5 & 5 & 0,938 & 2,316 & 14,622 & 8,037 & 57,138 \\
5,5 & 5,5 & 0,915 & 2,328 & 14,621 & 6,967 & 64,471 \\
6 & 6 & 0,902 & 2,363 & 13,780 & 4,958 & 77,003 \\
6,5 & 6,5 & 0,905 & 2,355 & 14,543 & 4,706 & 79,821 \\
7 & 7 & 0,907 & 2,351 & 15,144 & 4,279 & 83,363 \\
\hline
\end{tabular}

\section{Analisis Data Pengujian Marshall}

Pengujian Marshall ini didasarkan pada RSNI M-01-2003, didapatkan data seperti yang ditunjukkan pada Tabel 7. sebagai berikut:

Tabel 7. Rekapitulasi Sifat Campuran

\begin{tabular}{lcccccc}
\hline \multirow{2}{*}{ Sifat Campuran } & \multicolumn{3}{c}{ Kadar Aspal } & \multirow{2}{*}{ Persyaratan SNI } \\
\cline { 2 - 5 } & $5 \%$ & $5,5 \%$ & $6 \%$ & $6,5 \%$ & $7 \%$ & \\
\hline Stabilitas (kg) & 11350,631 & 1604,739 & 1740,450 & 1421,625 & 1307,905 & Min. 550 \\
Flow $(\mathrm{mm})$ & 2,77 & 3,17 & 3,90 & 4,07 & 4,57 & $2,0-4,0$ \\
MQ $(\mathrm{kg} / \mathrm{mm})$ & 488,94 & 508,47 & 446,88 & 349,82 & 286,01 & Min. 200 / Maks. 350 \\
Kepadatan (gr/cc) & 2,32 & 2,33 & 2,36 & 3,36 & 2,35 & $2-3$ \\
VIM (\%) & 8,04 & 6,97 & 4,96 & 4,71 & 4,28 & $3-5$ \\
VFB (\%) & 57,138 & 64,471 & 77,003 & 79,821 & 83,538 & Min. 78 / Maks. 82 \\
\hline
\end{tabular}

\section{Pembahasan Pengujian Marshall Test}

Dari hasil rekapitulasi sifat campuran selanjutnya dapat dibuat grafik hubungan kadar Semarbut Aspal Tipe III dengan nilai karakteristik Marshall seperti yang ditunjjukan pada Gambar 1. - 5. berikut:

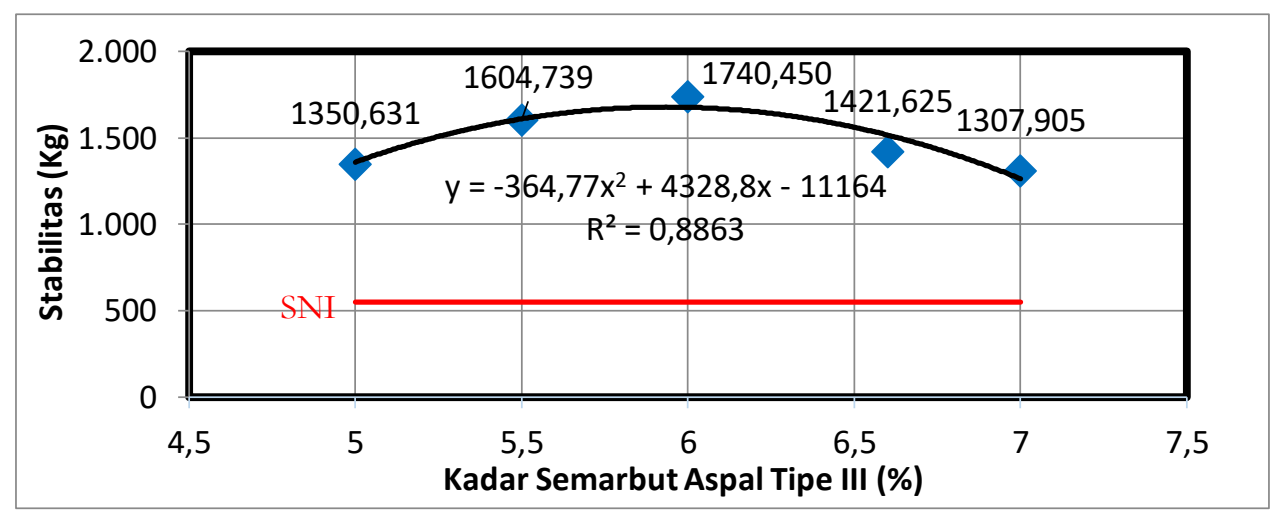

Gambar 1. Grafik Hubungan Kadar Semarbut Aspal Tipe III dengan Nilai Stabilitas

Gambar 1. di atas menunjukkan bahwa nilai stabilitas cenderung mengalami peningkatan sampai pada batas penambahan kadar aspal optimum rencana yaitu sebesar $6 \%$ kemudian mengalami penurunan. Dari hasil tersebut dapat diketahui bahwa kadar aspal mempengaruhi nilai stabilitas. Tingginya nilai stabilitas yang jauh di atas nilai minimum ini dapat dipengaruhi oleh kohesi aspal, gesekan antar partikel, penguncian antar partikel, proses pemadatan, dan mutu agregat yang digunakan. 


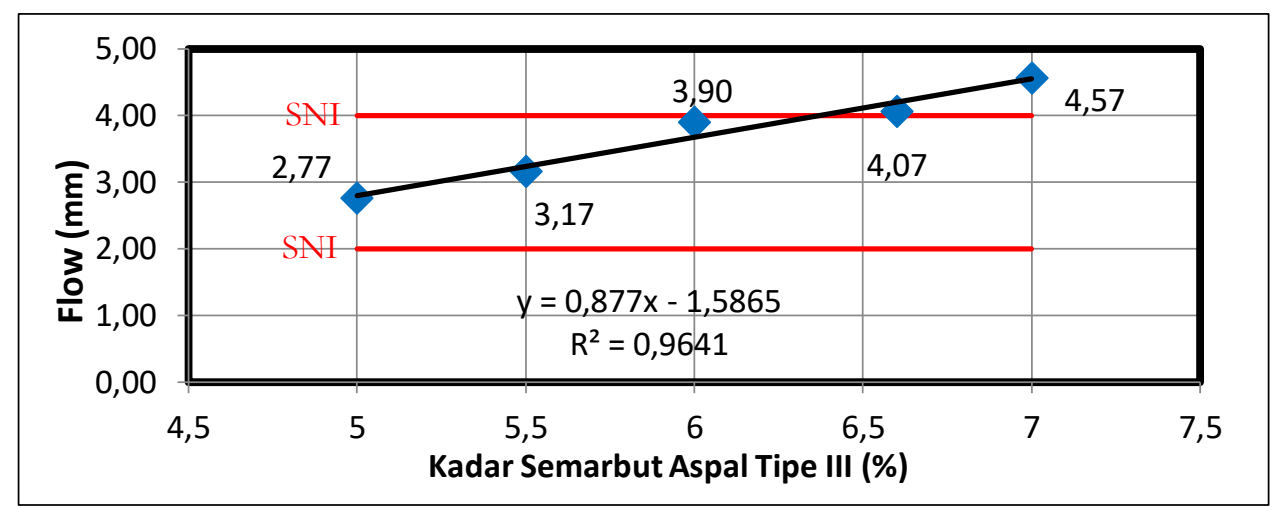

Gambar 2. Grafik Hubungan Kadar Semarbut Tipe III dengan Nilai Flow

Gambar 2. di atas dapat diketahui bahwa nilai Flow semakin naik seiring dengan peningkatan kadar aspal sehingga campuran cenderung bersifat plastis. Dari grafik di atas menunjukkan hanya pada penambahan kadar aspal 5\% $6 \%$ yang memenuhi persyaratan nilai Flow yaitu sebesar $2-4 \mathrm{~mm}$. Semakin tinggi nilai Flow campuran memiliki rongga udara yang kecil sebaliknya semakin kecil nilai Flow menunjukkan campuran memiliki rongga udara yang besar. Hal tersebut dapat dipengaruhi oleh gradasi agregat, mutu aspal, kadar aspal, dan proses pemadatan.

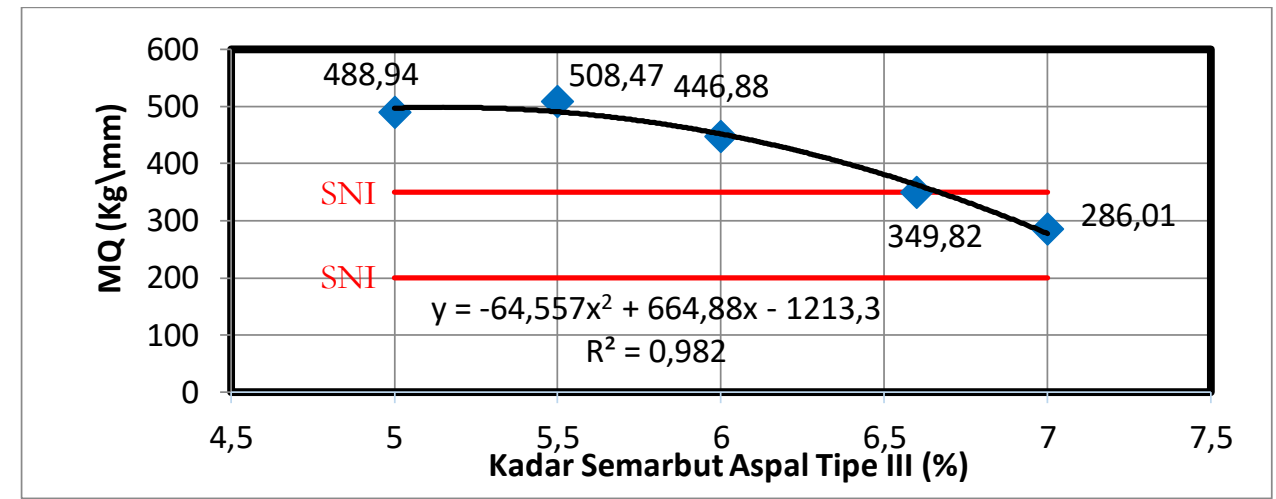

Grafik 3. Grafik Hubungan Kadar Semarbut Tipe III dengan Nilai Marshall Quotient

Gambar 3. di atas dapat diketahui bahwa peningkatan nilai Marshall Quotient terjadi pada penambahan kadar aspal $5 \%$ - 5,5\%, sedangkan pada penambahan kadar aspal 6\% - 7\% mengalami penurunan. Marshall Quotient merupakan indikator tingkat kekakuan dan fleksiblitas campuran. Semakin besar nilai Marshall Quotient pada suatu campuran aspal maka campuran semakin kaku memiliki stabilitas tinggi tetapi mudah retak dan sebaliknya semakin kecil nilai Marshall Quotient pada suatu campuran aspal maka campuran semakin lentur mudah berubah bentuk akibat pembebanan.

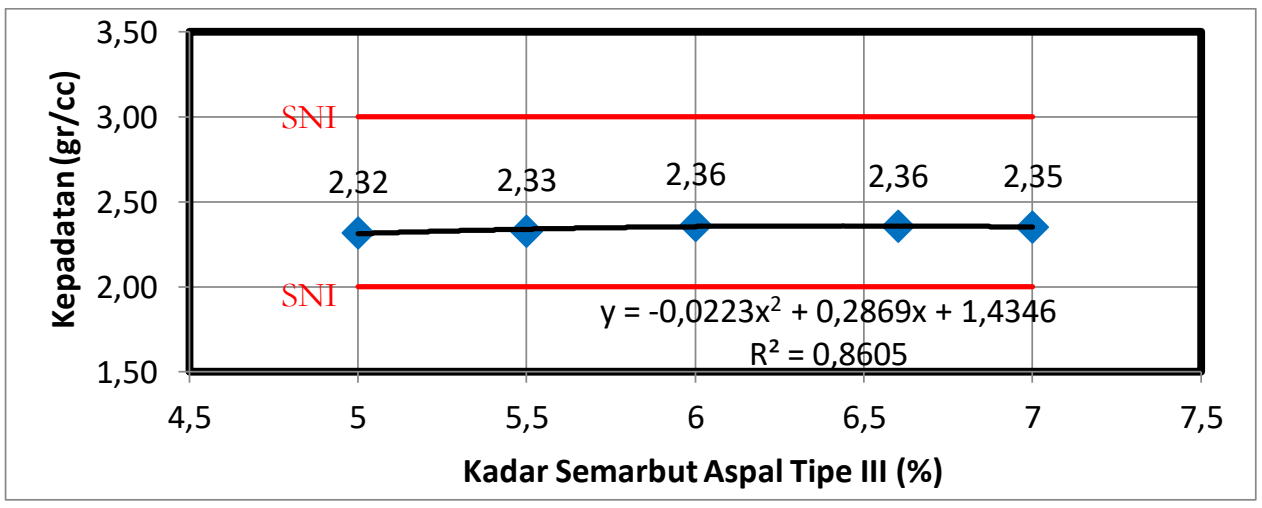

Grafik 4. Grafik Hubungan Kadar Semarbut Tipe III dengan Nilai Kepadatan

Gambar 4. di atas menunjukkan pada penambahan kadar aspal 5\% - 6\% mengalami peningkatan nilai kepadatan sedangkan pada kadar aspal 6,5\% - 7\% mengalami penurunan. Hal ini dapat dipengaruhi oleh gradasi agregat, kadar aspal, berat jenis agregat, dan proses pemadatan. Semakin padat campuran beraspal maka ikatan antar partikel 
dalam campuran semakin tinggi. Campuran beraspal yang memiliki nilai kepadatan tinggi cenderung lebih kuat menahan beban besar dibandingkan dengan campuran yang mempunyai nilai kepadatan rendah.

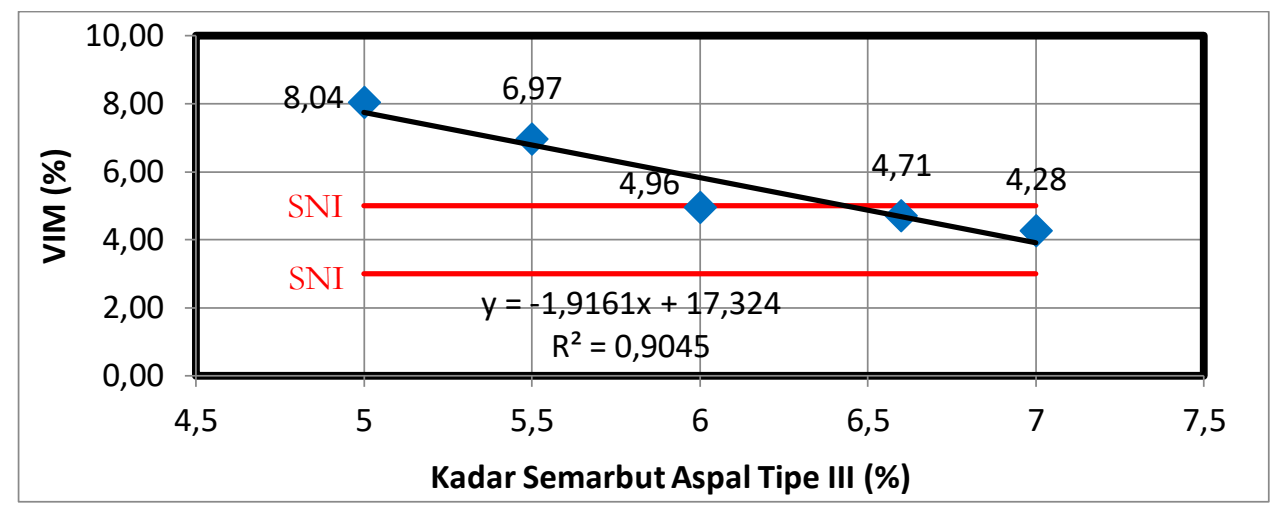

Grafik 5. Grafik Hubungan Kadar Semarbut Tipe III dengan Nilai VIM

Gambar 5. di atas menunjukkan penurunan nilai VIM terjadi seiring bertambahnya kadar aspal. Hal tersebut dapat dipengaruhi oleh gradasi agregat, kepadatan, dan proses penumbukan. Pada grafik di atas menunjukkan nilai VIM yang relatif tinggi dikarenakan masih terdapat rongga udara yang besar di dalam campuran. Tingginya nilai VIM pada campuran beraspal dapat menyebabkan durabilitas campuran aspal berkurang. Hal ini dikarenakan rongga udara yang terlalu besar memudahkan air dan udara masuk ke dalam lapisan perkerasan sehingga menyebabkan selimut aspal semakin mudah teroksidasi dan menjadi getas. Sedangkan jika nilai VIM pada suatu campuran beraspal rendah akan mengakibatkan bleeding. Semakin kecil rongga udara maka campuran beraspal akan semakin kedap air, tetapi udara tidak dapat masuk ke dalam lapisan beraspal sehingga menjadi rapuh dan getas.

\section{Analisis Kadar Optimum Aspal}

Kadar aspal optimum merupakan kadar aspal yang akan menghasilkan stabilitas campuran aspal yang paling baik. Penentuan kadar aspal optimum digunakan sebagai dasar dalam perhitungan kadar aspal untuk pembuatan benda uji Kuat Tarik. Untuk menentukan besarnya kadar aspal optimum dilakukan perhitungan persamaan regresi hubungan kadar Semarbut Aspal Tipe III dengan Nilai Stabilitas sebagai berikut:

$\mathrm{y}=-364,77 \mathrm{x}^{2}+4328,8 \mathrm{x}-11164$

y' $=0$

$\mathrm{y}^{\prime} \quad=-729,58 \mathrm{x}+4328,8$

$\mathrm{x}=5,93$

Setelah mendapatkan kadar aspal optimum, selanjutnya dibuat benda uji kuat tarik tidak langsung sebanyak 3 benda uji, dengan kadar aspal 5,93\%.

\section{Analisis Data Pengujian Kuat Tarik}

Pengujian Kuat Tarik menggunakan metode Kuat Tarik Tidak Langsung yang disesuaikan pada ASTM D4123-82. Hasil analisis data didapatkan sifat campuran yang ditunjukkan pada Tabel 8. sebagai berikut:

Tabel 8. Rekapitulasi Hasil Pengujian Kuat Tarik

\begin{tabular}{|c|c|c|c|c|}
\hline $\begin{array}{c}\text { Kode Benda } \\
\text { Uji }\end{array}$ & $\begin{array}{c}\text { Kadar Aspal } \\
(\%)\end{array}$ & $\begin{array}{c}\text { Regangan } \\
\text { (strain) }\end{array}$ & $\begin{array}{l}\text { ITS Terkoreksi } \\
(\mathrm{KPa})\end{array}$ & $\begin{array}{l}\text { Modulus Elastisitas } \\
\text { (Ksi) }\end{array}$ \\
\hline $\mathrm{A}$ & 5,93 & 0,00926 & 1167,22 & 18,29 \\
\hline B & 5,93 & 0,00858 & 1113,94 & 18,85 \\
\hline $\mathrm{C}$ & 5,93 & 0,00824 & 1057,58 & 18,64 \\
\hline \multicolumn{2}{|c|}{ Rata-Rata } & 0,00869 & 1112,91 & 18,59 \\
\hline
\end{tabular}

\section{Pembahasan Pengujian Kuat Tarik}

Modulus elastisitas merupakan indikator kekakuan suatu bahan. Semakin tinggi modulus elastisitas suatu campuran aspal maka perubahan bentuk yang terjadi tidak begitu banyak apabila diberi gaya. Dari hasil pengujian Kuat Tarik campuran panas asphalt concrete wearing course dengan bahan pengikat Semarbut Aspal Tipe III didapatkan nilai modulus elastisitas rata-rata yaitu sebesar 18,59 ksi. Nilai modulus elastisitas pada umumnya sekitar 500-2000 ksi, sehinngga hasil nilai modulus elastisitas yang diperoleh tergolong rendah dan mengakibatkan campuran cenderung kaku.

\section{Perbandingan Benda Uji Alat Pemadat Compactor dengan Benda Uji Alat Pemadat Vibrator}


Dalam pembuatan kedua benda uji, digunakan sumber dan gradasi agregat serta kadar aspal rencana yang sama. Dari analisis data pengujian Marshall Test dan Kuat Tarik didapatkan rekapitulasi sifat campuran disajikan selengkapnya pada Tabel 9. dan Tabel 10.

Tabel 9. Perbandingan Nilai Sifat Campuran dari Pengujian Marshall Test

\begin{tabular}{lccc}
\hline \multirow{2}{*}{ Sifat Campuran } & \multicolumn{2}{c}{ Benda Uji Pemadatan } & Persyaratan SNI \\
\cline { 2 - 3 } & Alat Compactor & Alat Vibrator & \\
\hline Stabilitas(kg) & 1678,68 & 374,71 & Min. 550 \\
Flow $(\mathrm{mm})$ & 3,6 & 2,6 & $2,0-4,0$ \\
MQ $(\mathrm{kg} / \mathrm{mm})$ & 459,3 & 149,5 & Min. 200 / Maks. 350 \\
Kepadatan $(\mathrm{gr} / \mathrm{cc})$ & 2,35 & 2,16 & $2-3$ \\
VIM $(\%)$ & 5,96 & 13,04 & $3-5$ \\
\hline
\end{tabular}

Tabel 10. Perbandingan Nilai Sifat Campuran dari Pengujian Kuat Tarik

\begin{tabular}{lcc}
\hline \multirow{2}{*}{ Sifat Campuran } & \multicolumn{2}{c}{ Benda Uji Pemadatan } \\
\cline { 2 - 3 } & Alat Compactor & Alat Vibrator \\
\hline Regangan & 0,00869 & 0,01190 \\
ITS $(\mathrm{KPa})$ & 1112,91 & 366,63 \\
Modulus Elastisitas $(\mathrm{kg} / \mathrm{mm})$ & 18,59 & 4,49 \\
\hline
\end{tabular}

Tabel 9. dan Tabel 10. di atas menunjukkan nilai karakteristik Marshall dan Kuat Tarik dari hasil pengujian dengan alat compactor dan vibrator memiliki perbedaan meskipun dengan sumber, gradasi agregat, dan jumlah kadar aspal rencana yang sama. Hal ini disebabkan oleh proses pemadatan yang berbeda, jika pemadatan menggunakan alat compactor benda uji dipadatkan secara menyeluruh seluas penampang mould, sedangkan pada alat pemadat vibrator benda uji dipadatkan per titik sehingga menyebabkan kepadatan tidak merata pada permukaan dan ketebalan benda uji. Selain itu, pada pemadatan menggunakan alat pemadat vibrator dilakukan dengan waktu yang relatif lama, sehingga menyebabkan suhu pencampuran tidak terkontrol. Faktor-faktor ini yang memungkinkan gesekan antar butiran agregat, dan daya ikat yang baik lapisan aspal pada campuran tidak bekerja dengan baik.

\section{SIMPULAN}

Berdasarkan penelitian yang telah dilakukan diperoleh hasil kadar aspal optimum campuran panas AC-WC menggunakan Semarbut Aspal Tipe III sebesar 5,93\%. Hasil uji Marshall dengan alat pemadat compactor diperoleh nilai stabilitas sebesar 1678,68 kg, nilai flow sebesar 3,6 mm, nilai MQ sebesar 459,3 kg/mm, nilai kepadatan sebesar 2,34 gr/cc, dan nilai VIM sebesar 5,96\%. Dari hasil tersebut dapat dilihat nilai stabilitas, flow, dan kepadatan telah memenuhi persyaratan, sedangkan nilai MQ dan VIM belum memenuhi persyaratan. Sedangkan hasil uji Kuat Tarik diperoleh nilai kuat tarik tidak langsung terkoreksi sebesar 1112,91 KPa, nilai regangan sebesar 0,00869 strain, dan nilai modulus elastisitas sebesar 18,59 Ksi. Hasil tersebut menunjukkan, bahwa nilai modulus elastisitas masih rendah dan belum memenuhi persyaratan. Hasil uji Marshall dengan alat pemadat vibrator diperoleh nilai stabilitas sebesar 374,71 kg, nilai flow sebesar 2,6 mm, nilai MQ sebesar 149,5 kg/mm, nilai kepadatan sebesar 2,16 gr/cc, dan nilai VIM sebesar 13,04\%. Dari hasil tersebut dapat dilihat nilai flow, dan kepadatan telah memenuhi persyaratan, sedangkan nilai stabilitas, MQ dan VIM belum memenuhi persyaratan. Sedangkan hasil uji Kuat Tarik diperoleh nilai kuat tarik tidak langsung terkoreksi sebesar 366,63 KPa, nilai regangan sebesar 0,0119 strain, dan nilai modulus elastisitas sebesar 4,49 Ksi, nilai tersebut lebih rendah jika dibandingkan benda uji alat compactor.

\section{REKOMENDASI}

1) Hasil stabilitas campuran yang tinggi pada benda uji alat pemadat compactor mengindikasikan campuran lebih kuat menahan beban, sehingga lebih cocok digunakan sebagai lapis pondasi atas.

2) Penelitian lebih lanjut menggunakan jenis campuran lain agar dapat diketahui karakteristik tiap campuran apabila menggunakan bahan pengikat yang sama.

3) Penelitian lebih lanjut dengan menggunakan bahan pengikat yang sama dengan pengujian yang berbeda.

4) Penelitian lebih lanjut disarankan pada proses pembuatan benda uji plat menggunakan alat pemadat dengan kepala penekan lebih besar dan dapat digerakkan, sehingga pemadatan lebih merata.

\section{REFERENSI}


Affandi, F., 2008. Karakteristik Bitumen Asbuton Butir untuk Campuran Beraspal Panas. Bandung: Pusat Litbang Jalan dan Jembatan.

Direktorat Jendral Bina Marga. 2006. Pemanfaatan Asbuton. Pedoman No: 001 - 01 / BM / 2006. Jakarta: Kementrian Pekerjaan Umum

Firmansyah Putra, Lazuardy, 2016. Karakteristik Campuran Panas Asphalt Concrete Wearing Course dengan Baban Pengikat Semarbut Tipe II. Surakarta: Universitas Sebelas Maret.

M. Hermadi, M. Sjahdanulirwan. 2008. Usulan Spesifikasi Campuran Beraspal Panas AsbutonLawele untuk Perkerasan Jalan. Bandung: Pusat Litbang Jalan dan Jembatan.

Mentari, Mantong C P. 2014. Penggunaan Campuran (AC-WC) Substitusi Buton Granular Aspal Sebagai Bahan Pengikat dengan Metode Marshall. Makasar: Universitas Hasanuddin.

Revisi SNI 03-1737-1989 : Pedoman Pelaksanaan Lapis Campuran Beraspal Panas, Badan Litbang Departemen Pekerjaan Umum. Bandung: Pusat Litbang Jalan dan Jembatan.

Richiantoro, Petrich M B. 2013. Tinjauan Karakteristik Marshall dan Kuat Tarik Tidak Langsung Campuran Panas Aspal Beton menggunakan Semarbut Aspal Tipe I sebagai Binder. Surakarta: Universitas Sebelas Maret.

Silvia, Sukirman. 2003. Beton Aspal Campuran Panas. Jakarta: Granit.

Wibowo, Luqman Try. 2016. Karakteristik Penambahan Ekstraksi Asbuton Emulsi pada Aspal Penetrasi 60/70 Sebagai Modifikasi Bitumen (Semarbut Aspal Tipe II). Surakarta: Universitas Sebelas Maret. 